\title{
23. INFERENCES ABOUT THE NATURE AND ORIGIN OF BASALT SEQUENCES FROM THE CRETACEOUS MID-PACIFIC MOUNTAINS (SITES 865 AND 866), AS DEDUCED FROM DOWNHOLE MAGNETOMETER LOGS ${ }^{1}$
}

\author{
Yoshifumi Nogi, ${ }^{2}$ John A. Tarduno, ${ }^{3}$ and William W. Sager ${ }^{4}$
}

\begin{abstract}
Downhole magnetometer logs from Sites 865 and 866 in the Cretaceous Mid-Pacific Mountains are used to constrain the nature and origin of the drilled igneous sections. These data provide information concerning the physical nature of basaltic flows that is not otherwise available because of poor core recovery. Magnetic boundaries, apparent inclination, and polarity of magnetization were determined from horizontal and vertical magnetic field variations in the hole.

The magnetization of basaltic sills at Allison Guyot (Site 865) was acquired in the Southern Hemisphere during the Cretaceous Normal Superchron. The inclination of primary magnetization is estimated to be between $27^{\circ}$ and $33^{\circ}$ from magnetometer logs.

Magnetic logs from near the top of the igneous section at Resolution Guyot (Site 866) suggest that magnetization was acquired in the Southern Hemisphere during a reversed polarity chron. The logs also suggest that the inclination of the primary magnetization is less than $35^{\circ}$. A significant contribution of induced magnetization to the seamount magnetization is suggested from a comparison of magnetometer data with paleomagnetic results.
\end{abstract}

\section{INTRODUCTION}

Seamount magnetic anomalies have been used to calculate mean seamount magnetizations, paleomagnetic poles, and polar wander paths of oceanic plates. Such analyses have been the basis for interpreting the nature of seamounts, studying seamount chain formation, and for making deductions about absolute plate motions (e.g., Sager and Pringle, 1988; Sager, 1992). However, the magnetization structures of most seamounts are unknown.

Recent studies of the magnetizations of rocks from seamounts or basaltic volcanoes suggest that the magnetizations are complicated by a varied lithology (Gee et al., 1988, 1989). An important implication of these studies is that the induced magnetization, assumed to be negligible in seamount paleomagnetic studies, may contribute significantly to seamount magnetic fields (Gee et al., 1989). Thus, although seamount basalts typically have a high Koenigsberger (Q) ratio (Furuta et al., 1980; Gee et al., 1988), the ratio of primary to induced magnetization, low-Q rocks may exist within a seamount to violate the paleomagnetic assumption. Indeed, several studies of seamount paleomagnetism obtained results that imply an induced overprint (Sager et al., 1993; Sager and Han, 1993).

Despite these conclusions, few data relating seamount rock magnetization to their magnetic fields exist. Typically, magnetic anomaly studies are performed on seamounts for which no samples are available. During Leg 143, we were able to collect downhole magnetic field logs within the basaltic sections of two seamounts that were drilled during the cruise: Allison Guyot (Site 865) and Resolution Guyot (Site 866). Such downhole magnetic logs can be useful for

\footnotetext{
'Winterer, E.L., Sager, W.W., Firth, J.V., and Sinton, J.M. (Eds.), 1995. Proc, ODP, Sci. Results, 143: College Station. TX (Ocean Drilling Program).

${ }^{2}$ Geochemical Research Department, Meteorological Research Institute, Tsukuba, Ibaraki 305, Japan. (Present address: National Institute of Polar Research, 1-9-10 Kaga, Itabashi, Tokyo 173, Japan.)

${ }^{3}$ Department of Earth and Environmental Sciences, University of Rochester, Rochester, NY 14627 , U.S.A.

${ }^{4}$ Department of Oceanography, Texas A\&M University, College Station, TX 77843 , U.S.A.
}

studying the magnetic structures in basaltic sections, particularly where core recovery is low. Furthermore, these logs allow one to examine in detail the relationship between sample magnetizations and magnetic field.

To date, downhole magnetic logs are rare, but have been obtained from oceanic crust (Ponomarev and Nekhoroshkov, 1983; Kinoshita et al., 1989; Hamano and Kinoshita, 1990; Pariso et al., 1991; Pariso and Johnson, 1993), where they have given evidence of the magnetic structure and the origin of magnetic lineations. In addition, a downhole proton precession magnetometer has been used along with a magnetic susceptibility log to construct a magnetic stratigraphy of sediments in a borehole in the Paris Basin (Pozzi et al., 1988; 1993). To our knowledge, the Leg 143 logs are the first such data from oceanic seamounts. In this study, we present interpretations, deduced from downhole magnetic measurements, about the nature of the basalts at Sites 865 and 866 .

\section{MAGNETIC LOGS}

Magnetic logs were obtained with the Japanese three-component downhole magnetometer. This device contains a three-axis fluxgate that allows for measurements of two horizontal components and one vertical component in the borehole to an accuracy of $2 \mathrm{nT}$.

Basalts were cored at Site 865 as three to four sills within a clayey limestone section in the bottom $34 \mathrm{~m}$ of Hole 865A (837-871 mbsf; Sager, Winterer, Firth, et al., 1993). The magnetometer was run from 500 to $865 \mathrm{mbsf}$ with sampling rate that gave a measurement spacing of $0.9 \mathrm{~m}$.

At Site 866, subaerial basalts were cored in the bottom $124 \mathrm{~m}$ of Hole 866A (1620-1744 mbsf; Sager, Winterer, Firth, et al., 1993). Magnetic log measurements were made from 1595 to 1636 mbsf, with sampling spacing of $0.3 \mathrm{~m}$ to obtain greater resolution. The penetration into the basalt section was only about $16 \mathrm{~m}$ because the unstable basalt collapse into the hole, creating a blockage.

\section{METHODS}

Assuming that the cross section of a hole is a perfect circle and that a cylindrical region around a hole is magnetized in a homogeneous manner, the vertical $\left(F_{Z}\right)$ and the horizontal $\left(F_{H}\right)$ fields at $z=z_{0}$ 
resulting from the magnetized body, bounded by $z=z_{I}$ and $z_{2}$, are expressed as ${ }^{\dagger}$

$$
\begin{aligned}
& F_{H}=\pi m \cos I \frac{z_{0}-z}{\sqrt{\left(z_{0}-z\right)^{2}+R^{2}}}\left|\begin{array}{l|l}
z_{2} \\
z_{1}
\end{array}\right| \begin{array}{l}
R_{2} \\
R_{1}
\end{array}, \\
& F_{Z}=2 \pi m \sin I \frac{z_{0}-z}{\sqrt{\left(z_{0}-z\right)^{2}+R^{2}}}\left|\begin{array}{l}
z_{2} \\
z_{1}
\end{array}\right| \begin{array}{l}
R_{2} \\
R_{1}
\end{array},
\end{aligned}
$$

where $m$ is the intensity of magnetization, $I$ is the inclination of the magnetization, and $R I$ and $R 2$ denote the radii of the hole and the cylindrical magnetized body, respectively (Hamano and Kinoshita, 1990).

If the present magnetic field at the site, such as the IGRF 1990 field (IAGA Division V Working Group 8, 1991), is known, the vertical $\left(F_{Z}\right)$ and horizontal fields $\left(F_{H}\right)$ caused by the surrounding magnetized body in the hole can be calculated by subtracting the present magnetic field at the site. The apparent inclination that results from a single, homogeneous, cylindrical magnetized body, can be obtained directly as follows:

$$
I=\tan ^{-1}=\left(-\frac{F_{Z}}{2 F_{H}}\right)^{2} .
$$

When the absolute values of the horizontal and vertical magnetic fields are not available, and only relative changes are measured, the spatial differential of both components can be used for calculation of the apparent inclination instead of the absolute values $F_{Z}$ and $F_{H}$. This relationship is easily derived from Equations 1 and 2, because the functions of both components are related to depth in the same manner.

Polarity of magnetization acquired in the Northern or Southern Hemisphere can be distinguished by the sign of both the horizontal and vertical fields from the surrounding magnetized material with respect to the present magnetic field at the site (Table 1).

Here, we define the intensity of the spatial differential of the downhole magnetic field (ISDDM) as follows:

$$
\left|\frac{d F}{d z}\right|=\sqrt{\left(\frac{d F_{H}}{d z}\right)^{2}+\left(\frac{d F_{z}}{d z}\right)^{2}}
$$

where $F_{H}$ and $F_{Z}$ are the horizontal and vertical magnetic fields resulting from the surrounding magnetized body. If there is enough distance between magnetic boundaries, ISDDM will exhibit a peak at the boundaries (Fig. 1). The vertical boundary resolution using ISDDM is about $2 \mathrm{~m}$ in an ODP borehole (Fig. 1). Therefore, magnetic boundaries can be determined by recognizing ISDDM peaks.

\section{DATA AND DATA PROCESSING}

Magnetic variations of the horizontal and vertical components between 500 and 862 mbsf were obtained at Site 865 and those between 1595 and 1638 mbsf at Site 866 . Obvious magnetic-field variations that correspond to basalt in the holes were observed below $835 \mathrm{mbsf}$ at Site 865 and below $1625 \mathrm{mbsf}$ at Site 866.

Problems occurred in both holes as a result of spurious variations caused by tool rotation. Below $650 \mathrm{mbsf}$ at Site 865 and below 1595 mbsf at Site 866 within the limestone and dolomite section, where the logging cable speed was less than $1000 \mathrm{~m} / \mathrm{hr}$, the horizontal and verti-

\footnotetext{
${ }^{\dagger}$ Here, we have followed the following notation convention:
}

$$
f(x, y) \mid \begin{array}{l|l}
x_{2} & \begin{array}{l}
y_{2} \\
x_{1}
\end{array} \\
y_{1}
\end{array}=f\left(x_{2}, y_{2}\right)-f\left(x_{2}, y_{1}\right),-f\left(x_{1}, y_{2}\right)+f\left(x_{1}, y_{1}\right) .
$$

cal magnetic field components are smooth, and only small spikes in the horizontal component and low amplitudes of sinusoidal magnetic variations $(<500 \mathrm{nT})$ in both components were observed. These sinusoidal magnetic variations are caused by the dip of the hole, accompanied with the slow rotation of the tool, derived from torsion of the wireline cable. In contrast, high-amplitude ( 30,000 nT), sharp decreases in the horizontal magnetic field were recorded above the aforementioned depths at each site, where the logging cable speed was faster than $2000 \mathrm{~m} / \mathrm{hr}$, but the vertical magnetic field variations are the same as observed below those depths. This suggests that these large variations were caused by the abrupt change of the tool orientation owing to the fast logging cable speed and the unstable hole conditions.

Horizontal and vertical magnetic variations between 700 and 800 mbsf at Site 865, and between 1595 and 1620 mbsf at Site 866, which correspond to a weakly magnetized section consisting of limestone and dolomite, were used to estimate the present magnetic field in each hole. Estimated present magnetic field in the holes, and the difference between that field and the IGRF 1990 magnetic field (IAGA Division V Working Group 8, 1991), are listed in Table 2. Estimated vertical and horizontal components of the present magnetic field were subtracted from horizontal and vertical magnetic fields measured in the holes.

The uncertainty from tool rotation was taken into account in the data processing as follows. A 1-m interval data set has been constructed from both upgoing and downgoing magnetometer logs at Site 865 to average out short-wavelength variations caused by tool rotation. The raw data from Site 866 were used because only upgoing magnetometer logs were recorded at Site 866. However, at this site, logging speed was about three times slower than that at Site 865 to reduce tool rotations.

The smoothed spatial differential of the vertical and horizontal components have been used to calculate the ISDDM and the apparent inclination to reduce the effects of tool rotation. The smoothing of the spatial differentials was made by fitting the data with a cubic polynomial function using a 9-m interval least-squares procedure (Savitzky and Golay, 1964). The simple model results show that the ISDDM curve, after the smoothing operation, has a vertical resolution of about $2 \mathrm{~m}$ (Fig. 1).

Magnetic boundaries were determined by calculating the ISDDM. Peak values of ISDDM higher than those that appeared in the limestone section caused by tool rotation were selected as magnetic boundaries in the igneous section. These boundaries were divided into two groups: peaks with troughs near zero on both sides were regarded as major magnetic boundaries, whereas the others were regarded as minor boundaries. Major magnetic units and subunits also were determined, using major and minor magnetic boundaries.

Apparent-inclination values were determined within the igneous rock section in each hole using the spatial differential of the vertical and horizontal components. To identify the polarity and the hemisphere of magnetization, both signs of horizontal and vertical magnetic variations with respect to the estimated horizontal and vertical components of the present magnetic field were used.

Paleomagnetic properties of discrete samples of basalts from Sites 865 and 866 were compared with downhole magnetometer logging results. As downhole susceptibility logs were not made, susceptibility measurements from discrete samples were used to constrain the contribution of induced magnetization to the downhole in situ magnetic variations.

\section{RESULTS}

\section{Site 865}

Downhole magnetometer logs from Site 865 are shown in Figure 2. Magnetic boundaries and units determined from ISDDM are summarized in Table 3. Paleomagnetic results are also listed in Table 4. Apparent inclination is presented only within magnetic units corresponding to igneous rock. 
A

A Magnetic Field (nT) Magnetic Field (nT) ISDDM (nT/m)

B

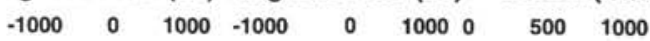

B Magnetic Field ( $\mathrm{nT}$ ) ISDDM (nT/m)

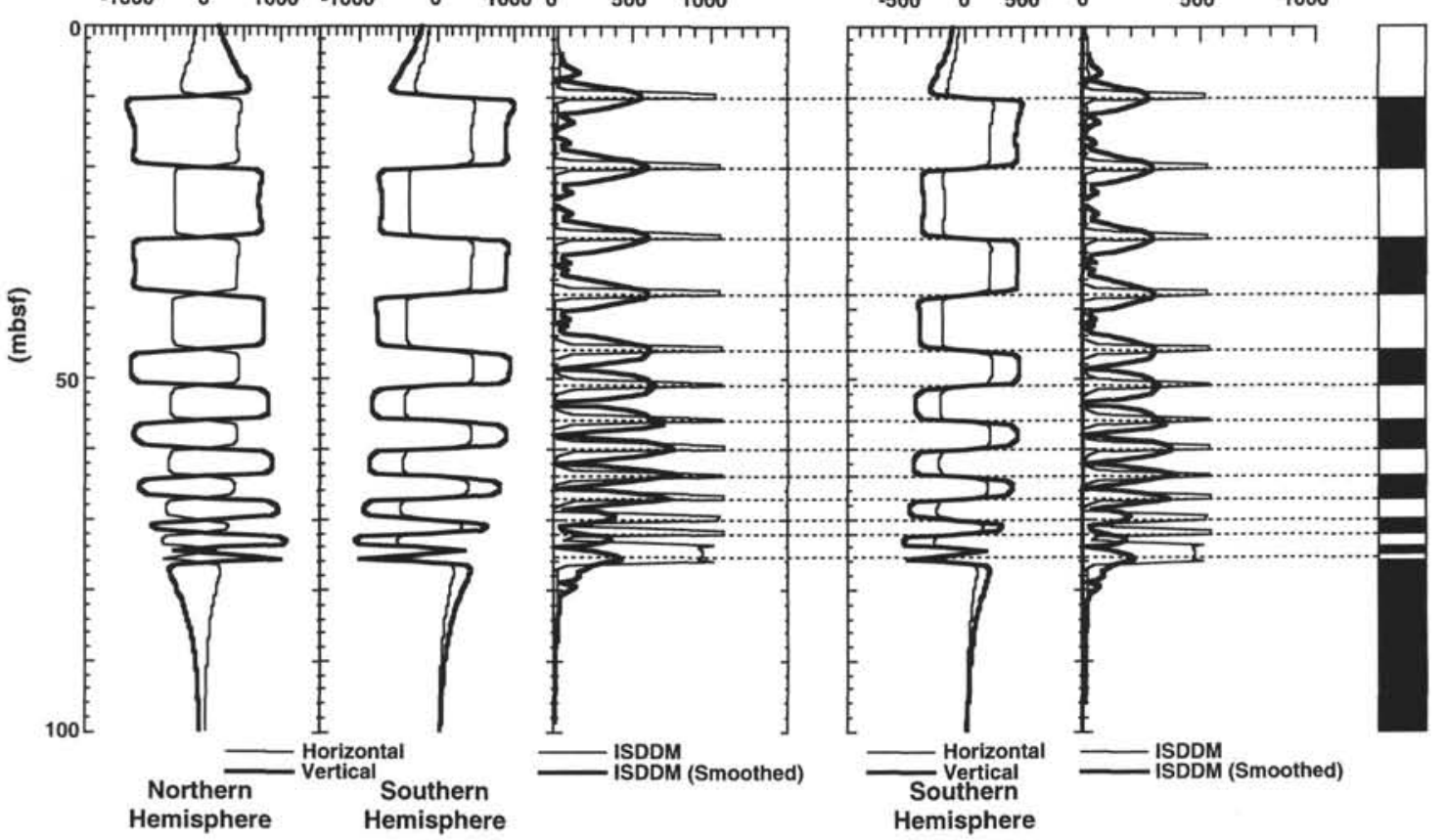

Figure 1. Magnetic-field variations of the vertical and horizontal components calculated from a circular hole model with cylindrical magnetization model, and variations of the intensity of the spatial differentials of the downhole magnetic field (ISDDM). Magnetic boundaries determined from ISDDM are shown by dashed lines. "ISDDM (smoothed)" indicates the smoothed ISDDM that was derived from a 9-m interval, least-square averaging procedure (Savitzky and Golay, 1964). Parameters used in the model are radius of cylindrical magnetized body $=10 \mathrm{~m}$, radius of the hole $=0.3 \mathrm{~m}$, inclination $=45^{\circ}$, and intensity $=1 \mathrm{~A} / \mathrm{m}$. A. Variations of magnetic field and the ISDDM resulting from magnetization acquired in the Northern or Southern Hemisphere, with a horizontal normal-reversed model; solid and open blocks at right are normal and reversed magnetized bodies, respectively, acquired in the Northern or Southern Hemisphere. B. Variations of magnetic field and the ISDDM resulting from horizontal unmagnetized (open blocks) and magnetized (solid blocks) layers acquired in the southern hemisphere during a normal polarity chron.

Three major magnetic units (magnetic Units 1-3) are identified, and two subunits also are suggested in Unit 3 from the ISDDM curve (Table 3). Magnetic boundaries determined from the ISDDM curve clearly show two major magnetic units between 838 and $846 \mathrm{mbsf}$ (Units 1 and 2) and also suggest that two subunits exist below $852 \mathrm{mbsf}$ (Subunits $3 \mathrm{~A}$ and $3 \mathrm{~B}$ ). The logging results suggest that the shallow igneous unit identified by the Shipboard Scientific Party within Core 143-865-90R is subdivided into two sills: Sill 1, 837-840 mbsf, and Sill 2, 843-845 mbsf. The shipboard unit spanning Cores 143-86593R to $-94 \mathrm{R}$ may also be composed of two sills (Sill $3 \mathrm{~A}, 852-856$ mbsf; Sill 3B, 856-859 mbsf), but this subdivision is less clear.

Calculated magnetizations in the igneous rock section indicate an origin in the Southern Hemisphere during a normal chron. The apparent inclinations of magnetic Unit 2 range from $-26^{\circ}$ to $-33^{\circ}$, which is in good agreement with natural remanent magnetization (NRM) values $\left(-30^{\circ}\right)$ derived from discrete shipboard paleomagnetic measurements. The apparent inclinations of magnetic Unit 1 and Subunit $3 \mathrm{~A}$ range from $-15^{\circ}$ to $-27^{\circ}$, and they are somewhat shallower than NRM values derived from discrete shipboard paleomagnetic measurements. In magnetic Subunit 3B, the apparent inclinations are highly variable and may have been affected by the drill bit, which was left at the bottom of the hole.

Discrete sample paleomagnetic results from magnetic Unit 2 show a high $Q$ ratio (Table 4). Thus, the magnetization of Unit 2 , if dominated by a remanent component, suggests that the inclinations of a characteristic magnetization range from $-26^{\circ}$ to $-33^{\circ}$, with an origin in the Southern Hemisphere during a normal polarity chron. The Q ratio of paleomagnetic results in magnetic Unit 3 is lower than that within magnetic Unit 2 (Table 4). An induced component would tend to cause the apparent inclination to be shallower than the paleomag-
Table 1. Polarity of magnetization and sign of the horizontal and vertical magnetic fields.

\begin{tabular}{clccc}
\hline Hemisphere & Polarity & $\begin{array}{c}\text { Sign of } \\
\text { horizontal field }\end{array}$ & $\begin{array}{c}\text { Sign of } \\
\text { vertical field }\end{array}$ & Z/H \\
\hline \multirow{2}{*}{ Northern } & $\begin{array}{l}\text { Normal } \\
\text { Southern }\end{array}$ & + & - & - \\
& $\begin{array}{l}\text { Reversed } \\
\text { Normal } \\
\text { Reversed }\end{array}$ & + & + & + \\
\hline
\end{tabular}

Note: $Z=$ vertical magnetic field, and $H=$ horizontal magnetic field.

netic inclination, as observed. No paleomagnetic results were obtained for magnetic Unit 1.

\section{Site 866}

Horizontal and vertical components of magnetic variation, ISDDM, and apparent inclination are shown in Figure 3. Magnetic boundaries and units determined from ISDDM and paleomagnetic results are listed in Tables 5 and 6, respectively.

The vertical magnetic field variations gradually decrease below $1621 \mathrm{mbsf}$, corresponding to the sediment/basalt contact. Clear magnetic boundaries can be observed at 1625 and $1629.1 \mathrm{mbsf}$.

Two major magnetic units were identified from the ISDDM curve. Magnetic Unit 1 (1625-1629.1 mbsf) shows the magnetization acquired in the Southern Hemisphere during a reversed chron. Highly altered basalt was recovered from this interval (Core 143-866A-171R).

A prominent magnetization in magnetic Unit 2 (>1629.1 mbsf) is a normal magnetization that originated in the Northern Hemisphere, 
Site 865

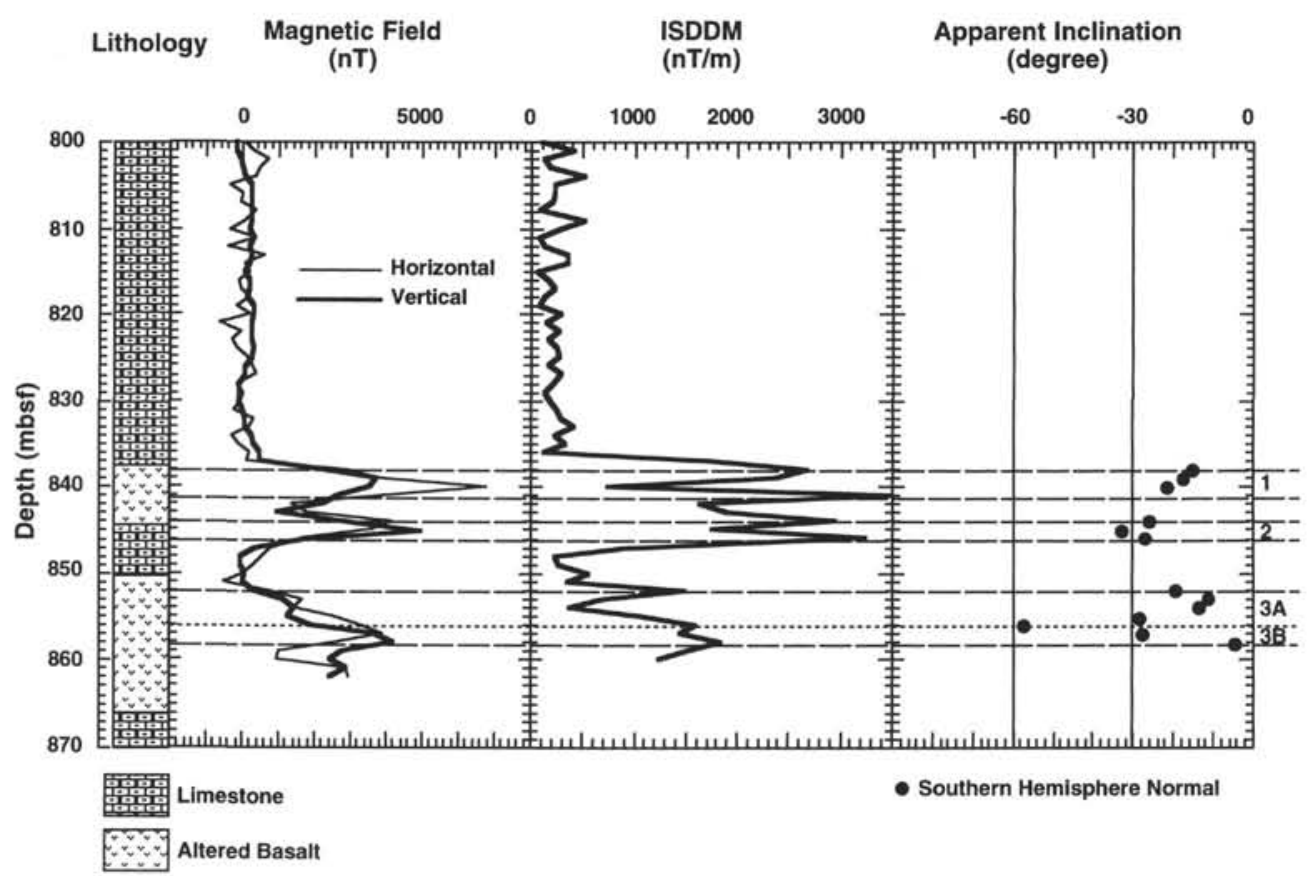

Figure 2. Variations of magnetic field and ISDDM and apparent inclination at Site 865. Summary of lithostratigraphy is also shown at left. Dashed and dotted lines denote major and minor magnetic boundaries, respectively, as determined from the ISDDM.

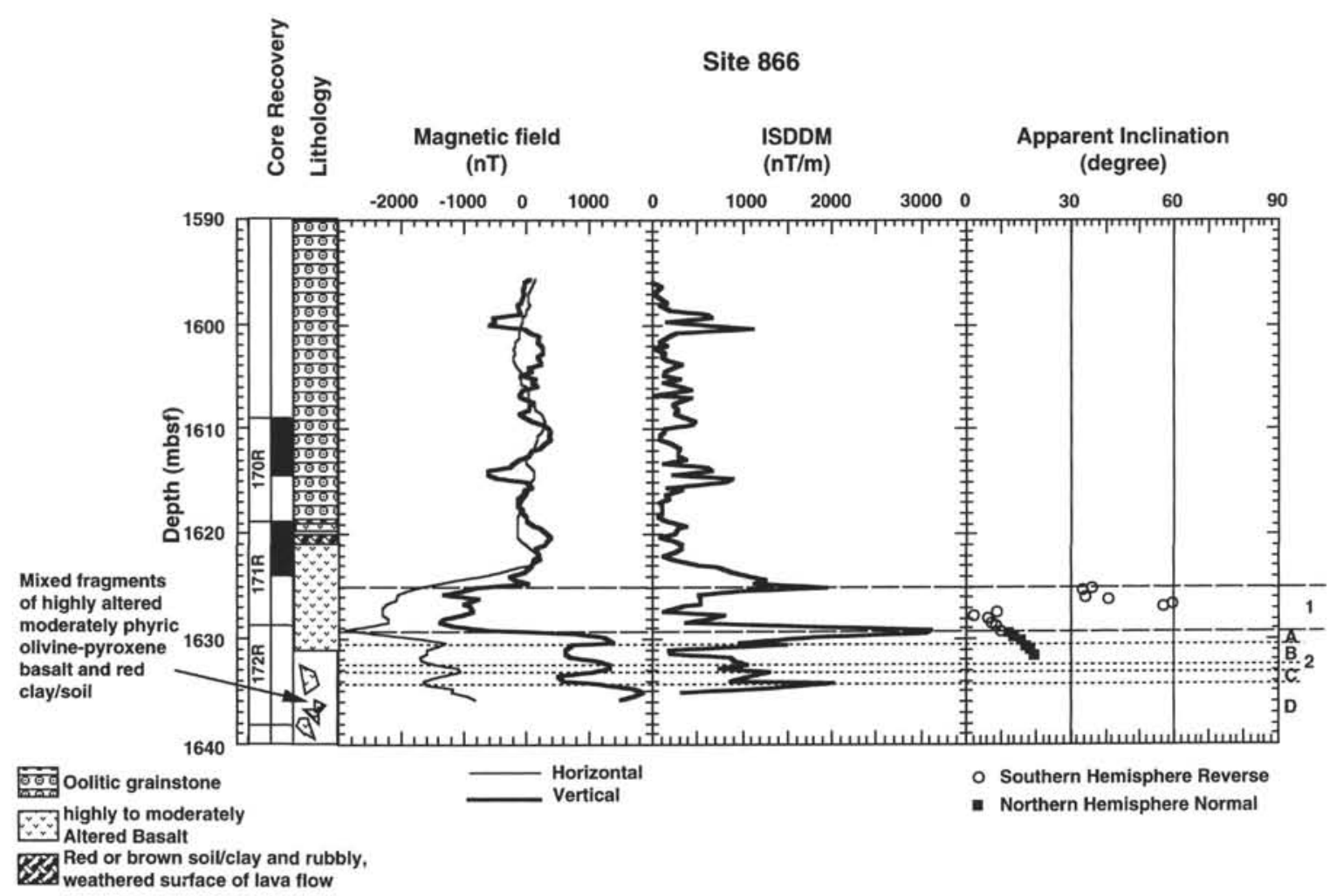

Figure 3. Variations of magnetic field and ISDDM and apparent inclination at Site 866. Core recovery and summary of lithostratigraphy are also shown at left. Dashed and dotted lines denote major and minor magnetic boundaries, respectively, as determined from the ISDDM. 
Table 2. Estimated magnetic field at Sites 865 and 866 and difference between that field and IGRF 1990 field.

\begin{tabular}{lccc}
\hline & $\begin{array}{c}\text { Horizontal } \\
\text { component } \\
\text { (nT) }\end{array}$ & $\begin{array}{c}\text { Vertical } \\
\text { component } \\
\text { (nT) }\end{array}$ & $\begin{array}{c}\text { Inclination } \\
\text { (degree) }\end{array}$ \\
\hline Site 865: & & & \\
$\quad$ Mean magnetic field (700-800 mbsf) & $28,998 \pm 455$ & $16,981 \pm 126$ & 30.4 \\
$\quad$ IGRF 1990 & 29,424 & 16,702 & 29.6 \\
Mean-IGRF 1990 & -426 & 279 & 0.8 \\
Site 866: & & & \\
$\quad$ Mean magnetic field (1595-1620 mbsf) & $28,568 \pm 233$ & $18,257 \pm 134$ & 32.6 \\
IGRF 1990 & 29,326 & 17,929 & 31.4 \\
Mean-IGRF 1990 & -758 & 328 & 1.2 \\
\hline
\end{tabular}

Table 3. Magnetic boundaries at Site 865 (determined from ISDDM).

\begin{tabular}{cc}
\hline $\begin{array}{c}\text { Magnetic } \\
\text { unit/subunit }\end{array}$ & $\begin{array}{c}\text { Range } \\
\text { (mbsf) }\end{array}$ \\
\hline 1 & $838-841$ \\
2 & $844-846$ \\
3A & $852-856$ \\
3B & $856-858$ \\
\hline
\end{tabular}

Table 4. Summary of paleomagnetic properties of basalts recovered at Site 865 .

\begin{tabular}{crrrr}
\hline $\begin{array}{c}\text { Sample } \\
\text { depth } \\
\text { (mbsf) }\end{array}$ & $\begin{array}{c}\text { Intensity } \\
(\mathrm{A} / \mathrm{m})\end{array}$ & $\begin{array}{c}\text { Susceptibility } \\
\left(10^{-3} \mathrm{~S}\right)\end{array}$ & Q ratio & $\begin{array}{c}\text { Inclination } \\
\text { (degree) }\end{array}$ \\
\hline 842.2 & 19.8 & 13.1 & 56.5 & -32.6 \\
842.3 & 9.5 & 9.5 & 37.4 & -33.1 \\
843.1 & 10.3 & 11.8 & 32.6 & -35.4 \\
843.4 & 6.4 & 9.1 & 26.3 & -27.9 \\
843.5 & 11.7 & 12.4 & 35.3 & 29.8 \\
843.6 & 9.9 & 10.2 & 36.3 & -41.2 \\
844.0 & 24.6 & 8.8 & 104.5 & -35.0 \\
844.2 & 7.3 & 24.8 & 11.0 & -29.9 \\
855.0 & 3.4 & 11.4 & 11.2 & -52.7 \\
855.9 & 3.3 & 30.3 & 4.1 & -66.1 \\
856.1 & 1.2 & 28.5 & 1.5 & 43.7 \\
856.4 & 3.2 & 13.1 & 9.0 & -68.1 \\
856.6 & 1.0 & 22.7 & 1.6 & -30.6 \\
857.2 & 4.5 & 14.0 & 12.0 & -29.0 \\
863.9 & 2.9 & 8.0 & 13.6 & 11.6 \\
864.2 & 8.4 & 9.9 & 31.8 & 1.8 \\
864.3 & 0.2 & 9.0 & 0.7 & -25.1 \\
864.9 & 3.6 & 5.5 & 24.4 & -7.8 \\
868.5 & 1.2 & 8.6 & 5.1 & -2.9 \\
868.6 & 5.6 & 8.5 & 24.6 & 54.8 \\
\hline
\end{tabular}

Note: NRM values are listed.

Table 5. Magnetic boundaries at Site 866 (determined from ISDDM).

\begin{tabular}{cc}
\hline $\begin{array}{c}\text { Magnetic } \\
\text { unit/subunit }\end{array}$ & $\begin{array}{c}\text { Range } \\
(\mathrm{mbsf})\end{array}$ \\
\hline 1 & $1625-1629.1$ \\
$2 \mathrm{~A}$ & $1629.1-1630.6$ \\
$2 \mathrm{~B}$ & $1630.6-1632.5$ \\
$2 \mathrm{C}$ & $1633.2-1634.3$ \\
2D & $1634.3->1635$
\end{tabular}

suggesting the dominance of the present-day field. Core recovery in magnetic Unit 2 was poor. The minimal core recovered, however, suggests a stratigraphy of altered basalt fragments embedded in a redbrown clay/soil matrix and was interpreted on board the ship as a debris flow or talus deposit. Magnetization deduced from downhole magnetometer logs is consistent with this interpretation; the most altered basalt or soil likely carries a viscous overprint of the present-day field.

Magnetic Unit 2 also contains four magnetic subunits (2A-2D). In magnetic Subunits $2 \mathrm{~B}$ and $2 \mathrm{C}$, both horizontal and vertical mag-
Table 6. Summary of paleomagnetic properties of basalts recovered in Site 866.

\begin{tabular}{|c|c|c|c|c|}
\hline $\begin{array}{l}\text { Sample } \\
\text { depth } \\
\text { (mbsf) }\end{array}$ & $\begin{array}{l}\text { Intensity } \\
(\mathrm{A} / \mathrm{m})\end{array}$ & $\begin{array}{l}\text { Susceptibility } \\
\left(10^{-3} \mathrm{SI}\right)\end{array}$ & $Q$ ratio & $\begin{array}{c}\text { Inclination } \\
\text { (degree) }\end{array}$ \\
\hline 1660.38 & 1.1 & 26.20 & 1.5 & 39.5 \\
\hline 1660.91 & 5.5 & 23.80 & 8.6 & -18.6 \\
\hline 1661.79 & 2.2 & 56.70 & 1.4 & 61.5 \\
\hline 1661.93 & 1.4 & 53.90 & 1.06 & 1.6 \\
\hline 1663.24 & 10.2 & 52.10 & 7.2 & -10.6 \\
\hline 1664.37 & 2.6 & 52.60 & 1.84 & 6.6 \\
\hline 1665.39 & 2.2 & 52.50 & 1.5 & 57.8 \\
\hline 1667.69 & 5.1 & 42.40 & 4.5 & 77.9 \\
\hline 1669.23 & 6.8 & 40.60 & 6.2 & 73 \\
\hline 1670.41 & 5.5 & 55.80 & 3.6 & 61.5 \\
\hline 1671.85 & 9.2 & 42.90 & 8.0 & 54.3 \\
\hline 1673.58 & 2.0 & 4.75 & 15.7 & 33.7 \\
\hline 1673.72 & 0.5 & 1.68 & 10.8 & 35.4 \\
\hline 1673.94 & 1.7 & 12.34 & 5.2 & 36.1 \\
\hline 1674.61 & 1.6 & 13.72 & 4.3 & 30 \\
\hline 1674.78 & 3.1 & 31.72 & 3.7 & 5.3 \\
\hline 1678.99 & 1.3 & 43.00 & 1.1 & 26.6 \\
\hline 1679.04 & 1.2 & 39.10 & 1.1 & 13.9 \\
\hline 1679.11 & 3.9 & 46.30 & 3.1 & 26.7 \\
\hline 1679.15 & 4.6 & 49.60 & 3.4 & 24.5 \\
\hline 1682.88 & 2.5 & 48.20 & 1.9 & 37.1 \\
\hline 1684.82 & 2.0 & 24.00 & 3.0 & 59.6 \\
\hline 1685.7 & 2.5 & 42.60 & 2.2 & 65.2 \\
\hline 1686.92 & 0.7 & 10.80 & 2.5 & 29.4 \\
\hline 1687.18 & 1.0 & 37.62 & 0.9 & 24.4 \\
\hline 1687.51 & 1.3 & 33.10 & 1.4 & 15.8 \\
\hline 1687.56 & 1.8 & 26.22 & 2.5 & 37 \\
\hline 1687.67 & 4.3 & 15.52 & 10.3 & 1.4 \\
\hline 1687.36 & 2.5 & 54.00 & 1.7 & 19 \\
\hline 1687.76 & 1.9 & 48.40 & 1.5 & 17.4 \\
\hline 1688.69 & 2.4 & 76.90 & 1.2 & 7 \\
\hline 1692.64 & 6.4 & 49.10 & 4.8 & 21.2 \\
\hline 1693.33 & 2.2 & 66.90 & 1.2 & 54.6 \\
\hline 1693.92 & 0.5 & 3.08 & 5.7 & 23.4 \\
\hline 1694.25 & 1.4 & 19.82 & 2.7 & 17.5 \\
\hline 1694.34 & 1.4 & 19.30 & 2.6 & 28.5 \\
\hline 1694.67 & 0.4 & 31.30 & 0.5 & 9.7 \\
\hline 1695.09 & 0.2 & 17.50 & 0.5 & 64.6 \\
\hline 1695.32 & 0.5 & 26.10 & 0.7 & 10.2 \\
\hline 1698.42 & 3.8 & 25.50 & 5.5 & 44.8 \\
\hline 1699.3 & 0.3 & 22.40 & 0.5 & 77.6 \\
\hline 1699.91 & 0.5 & 23.50 & 0.8 & 38.2 \\
\hline 1700.92 & 2.7 & 17.90 & 5.6 & 39.1 \\
\hline 1708.19 & 10.1 & 23.90 & 15.6 & 18.4 \\
\hline 1709.56 & 5.3 & 21.60 & 9.1 & 15.9 \\
\hline 1710.16 & 8.7 & 47.20 & 6.8 & -19.8 \\
\hline 1717.64 & 3.2 & 40.30 & 3.0 & 20.5 \\
\hline 1717.87 & 2.8 & 30.80 & 3.3 & -17 \\
\hline 1727.48 & 10.1 & 46.70 & 8.0 & 31.6 \\
\hline 1727.62 & 11.1 & 35.90 & 11.4 & 28.7 \\
\hline 1727.66 & 8.4 & 27.40 & 11.3 & 27.8 \\
\hline 1729.08 & 1.7 & 23.90 & 2.7 & 18.9 \\
\hline 1729.46 & 2.8 & 29.30 & 3.6 & 16.2 \\
\hline 1729.81 & 4.6 & 40.40 & 4.2 & 18.7 \\
\hline 1730.04 & 3.7 & 57.00 & 2.4 & 15.8 \\
\hline 1730.35 & 2.5 & 31.10 & 3.0 & 12.1 \\
\hline 1730.87 & 2.4 & 21.00 & 4.3 & 15.8 \\
\hline 1735.12 & 0.8 & 20.90 & 1.5 & -49.9 \\
\hline 1735.31 & 1.2 & 22.90 & 1.9 & 6.9 \\
\hline 1735.68 & 0.8 & 23.20 & 1.2 & -2.4 \\
\hline 1737.67 & 0.8 & 40.70 & 0.8 & 5.1 \\
\hline 1737.79 & 3.7 & 41.80 & 3.3 & 18.6 \\
\hline 1738.17 & 1.4 & 36.00 & 1.5 & -46.3 \\
\hline 1738.34 & 1.1 & 37.40 & 1.1 & -18.8 \\
\hline 1739.3 & 5.9 & 69.90 & 3.1 & -9.5 \\
\hline 1739.33 & 4.8 & 60.50 & 2.9 & -10.1 \\
\hline
\end{tabular}

Note: NRM values are listed. 
netic fields decrease in approximately the same sense. Although a normal Northern Hemisphere magnetization is dominant in magnetic Unit 2, this variation implies thin magnetized layers in magnetic Subunits $2 \mathrm{~B}$ and $2 \mathrm{C}$, which were magnetized in the Southern Hemisphere during a reversed polarity chron. It is these thin layers that we consider to be weathered basalt flows, rather than clasts in a debrisflow deposit.

An apparent inclination calculated from the logs near magnetic boundaries at $1625 \mathrm{mbsf}$ in magnetic Unit 1 is about $35^{\circ}$. Below the position where apparent inclination is about $35^{\circ}$, the apparent inclination becomes steeper, but returns to almost $0^{\circ}$ at about $1628 \mathrm{mbsf}$, near the next clear magnetic boundary at 1629.1 mbsf. Because a 25point, smoothed differential value was used, the apparent inclination below $1626 \mathrm{mbsf}$ is affected by the magnetization of magnetic Unit 2 .

\section{DISCUSSION}

The magnetic field of the upper section of the igneous rock in Allison Guyot (Site 865) appears to have formed during the Cretaceous Normal Superchron (83.00-124.32 Ma; Harland et al., 1990) in the Southern Hemisphere. Radiometric age dates from those samples suggest possibly two ages, about 111 and $105 \mathrm{Ma}$ (Pringle and Duncan, this volume), and these ages are within the Cretaceous Normal Superchron.

The uppermost igneous section of Resolution Guyot (Site 866) also formed in the Southern Hemisphere, but in a reversed polarity chron, possibly older than Chron M5 (Tarduno et al., this volume). Two mean radiometric dates were determined from the Site 866 basalts: 128 and $122 \mathrm{Ma}$ (Pringle and Duncan, this volume). The uppermost samples, close to the position where downhole magnetometer logs were recorded, indicate an age of $128 \mathrm{Ma}$ from radiometric age dates and belong to the oldest lavas (Pringle and Duncan, this volume). This age places the basalt within the M-reversal sequence in most time scales. An exact identification of the reversed polarity chron recorded by the shipboard paleomagnetic results and downhole magnetometer logs, however, will require further work.

The inclination of primary magnetization is likely between $-27^{\circ}$ and $-33^{\circ}$ for Site 865 , as estimated by the downhole magnetometer results. Because the dip data from the Formation MicroScanner (FMS) did not show significant dipping contacts within the igneous section at Site 865 , the apparent inclination should not be affected by the dipping of the basaltic sills. The apparent inclination most likely reflects a primary magnetization and induced or viscous overprinting magnetization. Apparent inclinations become shallower at Site 865, if an induced or viscous magnetization is added to the primary magnetization, acquired in the Southern Hemisphere during a normal chron (Fig. 4). The shallower apparent inclinations from downhole magnetometer logs in magnetic Unit 1 and Subunit $3 \mathrm{~A}$ of Site 865 rather than a characteristic remanent magnetization (ChRM) inclination of $31^{\circ}$ (Fig. 2), which was derived from shipboard paleomagnetic results (Sager, Winterer, Firth, et al., 1993). This can be explained by the contribution of induced or viscous magnetization. The maximum value of apparent inclination in magnetic Unit 1 and Subunit $3 \mathrm{~A}$ of Site 865 is about $27^{\circ}$; therefore, the inclination of the primary magnetization should be greater than or equal to $27^{\circ}$. In magnetic Unit 2 of Site 865, where high Q ratios ( $>30$ ) were observed from discrete sample paleomagnetic results, the apparent inclination ranges from $27^{\circ}$ to $33^{\circ}$. If the total magnetization consists of only primary and induced magnetization, and considering the case when Q is $>25$, the difference between the observed and primary inclinations is less than $2^{\circ}$. Thus, the inclination of the primary magnetization of the basaltic sills at Site 865 is probably between about $27^{\circ}$ and $33^{\circ}$. This inclination is in agreement with a ChRM inclination of $31^{\circ}$, which was derived from shipboard paleomagnetic results on the basalts (Sager, Winterer, Firth, et al., 1993).

As at Site 865, no significant dips were obtained from dip data of FMS logs within the upper igneous rock section of Site 866 . For a magnetization acquired in the Southern Hemisphere during a reversed chron, an induced or viscous magnetization makes the observed in situ inclination steeper (Fig. 4). Thus, the inclination of primary magnetization for the upper igneous rock section of Site 866 is less than $35^{\circ}$. Apparent inclination near the top of the igneous section in magnetic Unit 1 is $35^{\circ}$, and this is the minimum inclination value, except for that of the lower part of magnetic Unit 1, which is affected by magnetization of magnetic Unit 2 . Consequently, the inclination of primary magnetization should be less than $35^{\circ}$, if the magnetization were caused by a primary magnetization originating in the Southern Hemisphere plus an induced magnetization. Inclination groups derived from shipboard paleomagnetic measurements near the top of the igneous interval from Sections 143-866A-171R-3 to -179R-2 give an average of $32.0^{\circ}$ (Sager, Winterer, Firth, et al., 1993), and this result agrees with the inclination deduced from downhole magnetometer logs.

A significant contribution of induced magnetization is suggested by discrete sample paleomagnetic results from Site 866 . Histograms of Q ratios, obtained by discrete sample paleomagnetic study, are shown in Figure 5. Almost all Q ratio values from the Site 866 basalts are low, between 1 and 6 . In contrast, the Q ratios from the basaltic sills at Site 865 are one order of magnitude higher (but the number of samples is much smaller). The difference in the Q-ratio distribution between the two sites may reflect differences in the processes of formation and subsequent alteration. Basaltic sills at Site 865 are thought to be intrusive into limey sediments that became limestone. Apparently, the intrusion occurred below sea level, but near the seafloor. Because of the possible interaction with seawater, cooling may have been rapid. Rapid cooling often results in fine grain sizes that often carry stable magnetization (e.g., O'Reilly, 1984). Basalts of Site 866, on the other hand, probably in part formed above sea level and may have cooled more slowly. In addition. they were exposed to subaerial weathering conditions, which could account for the lower $\mathrm{Q}$ ratios.

The estimated Q ratio from the apparent inclination values is about 18 for the top of Magnetic Unit 1 at Site 866, assuming that the inclination value of $32^{\circ}$, derived from shipboard paleomagnetic results of the upper igneous section (Sager, Winterer, Firth, et al., 1993), is an inclination value of primary magnetization. This is slightly higher than the average $Q$ ratio from paleomagnetic results, but within the $Q$ ratio range obtained at Site 866 . Grain size of the basalt decreases toward the contact with the limestone, and that of the lowermost igneous section is larger than that of the uppermost section (Sager, Winterer, Firth, et al., 1993). Because Q ratio is related to grain size, this suggests that the $Q$ ratio of the top of the basalt at Site 866 is relatively higher than that of the inner part of basaltic flows, as an inner part of basaltic flows may cool more slowly than the top of the basalt. The estimated $Q$ ratio from the magnetometer logs ranges between 3 and 25 for magnetic Units 1 and 2 and Subunit $3 \mathrm{~A}$ of Site 865 , assuming that the inclination of primary magnetization is about $31^{\circ}$, as from shipboard paleomagnetic results. These results are in agreement with the $\mathrm{Q}$ ratio from paleomagnetic results. Close relationship between $\mathrm{Q}$ ratio and apparent inclination suggests that induced magnetization is dominant over viscous overprinting.

Results from downhole magnetometer logs and paleomagnetic study suggest a significant contribution to borehole geomagnetic field from induced magnetization. A high $Q$ ratio was observed only in some samples of basaltic sills at Site 865 . Thus, estimates of paleomagnetic data from seamount magnetic field are probably biased by the induced component, as suggested by Gee et al. (1989). These conclusions, of course, depend upon how typical are the basalts at Site 866 . They appear to be typical subaerial basalts and, thus, could be expected to be in most large seamounts. The Site 865 basalts, with generally high Q ratios, may be less typical because they appear to be last-stage eruptive products intruded into sediments after the erosion and subsidence of the volcano.

The close correspondence of magnetization values derived from logs and NRM and ChRM values derived from discrete paleomag- 
A

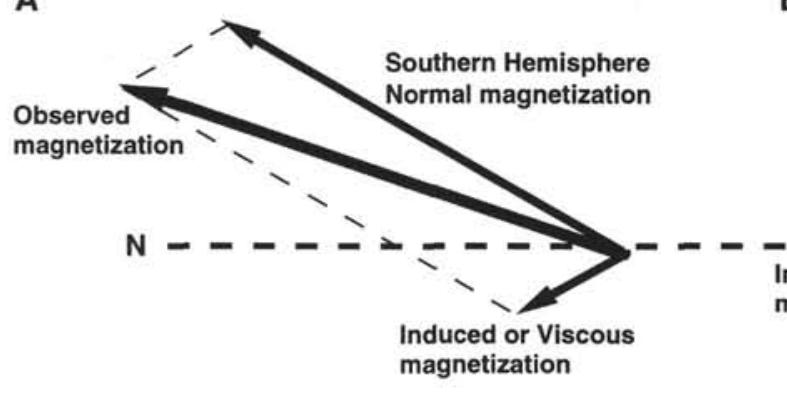

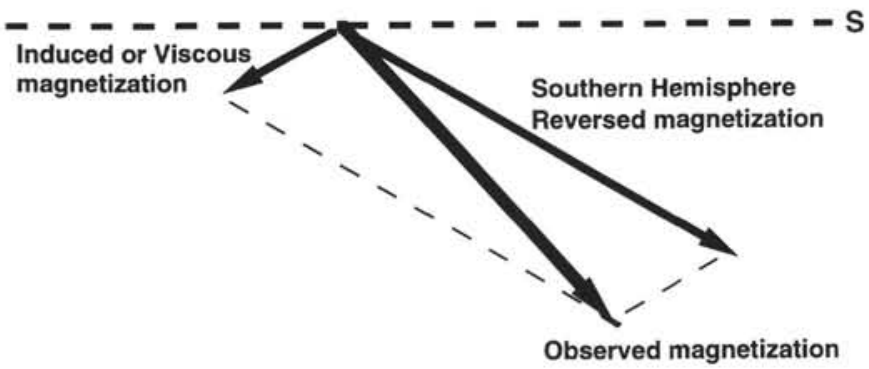

Figure 4. Explanation for the shallower and steeper apparent inclinations for (A) Site 865 and (B) Site 866. The ratio of primary magnetization to induced or viscous magnetization ( $Q$ ratio) used for this illustration is 5 .

netic specimens highlights a promising future for magnetic-log programs. The reliability of such logs in approximating NRM and ChRM values, as a result of the overprinting potential of induced and viscous magnetization, however, will always hinder their use for deriving paleomagnetic pole data. Trends in magnetic susceptibility data from Leg 143 discrete samples suggest that downhole magnetic susceptibility logs may provide sufficient information to constrain induced component of magnetization. Downhole susceptibility data could be used to choose intervals objectively for which the assumption of a magnetization dominated by characteristic magnetization is likely to be correct. In addition, the potential of fully oriented data (magnetometer with gyro) will provide the declination of surrounding magnetized materials. Information on declination can be used to determine the apparent polar path and/or block rotation of the region near the hole.

\section{SUMMARY AND CONCLUSIONS}

Magnetic boundaries, apparent inclination, polarity of magnetization, and the hemisphere (Northern or Southern) of magnetization were determined from horizontal and vertical magnetic-field variations within drill holes at Allison (Site 865) and Resolution (Site 866) guyots. The magnetization of basaltic sills at Allison Guyot (Site 865) was acquired in the Southern Hemisphere during the Cretaceous Normal Superchron. The inclination of primary magnetization of these sills is estimated between $27^{\circ}$ and $33^{\circ}$, assuming that the magnetization result only from primary and induced magnetization. In contrast, magnetization near the top of the igneous section at Resolution Guyot (Site 866 ) indicates that the magnetization was acquired during a reversed polarity chron. The inclination of primary magnetization is estimated to be less than $35^{\circ}$. The downhole magnetometer logs and paleomagnetic results suggest that induced magnetization contributed significantly to the seamount magnetization of these basalts.

\section{ACKNOWLEDGMENTS}

Y.N. thanks N. Seama, T. Yamazaki, C. Itota, and Y. Otofuji for discussions and comments. Critical reviews by Y. Hamano and J. P. Pozzi are also appreciated. The downhole three-component magnetometer was developed and fabricated by Meisei Electronic Co., Inc. The magnetometer was calibrated at Kakioka Magnetic Observatory. Y.N. is grateful to the members of the Geochemical Research Department, Meteorological Research Institute, for their understanding and interest in our observations. We thank the Ocean Research Institute, University of Tokyo, and the Ocean Drilling Program for the opportunity of participating in Leg 143.
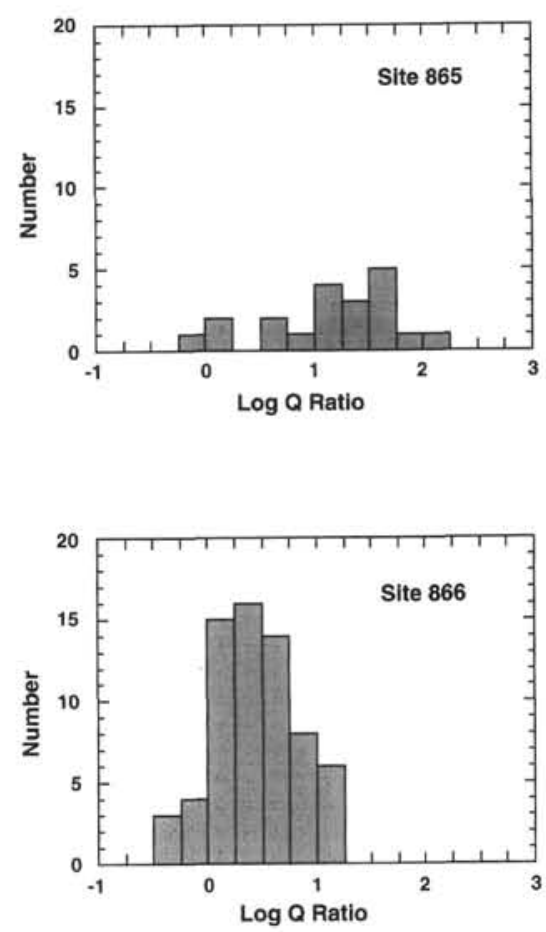

Figure 5. Q ratios for samples recovered at Sites 865 and 866 .

\section{REFERENCES}

Furuta, T., Tonouchi, S., and Nakada, M., 1980. Magnetic properties of pillow basalt from the Kinan seamount chain, the Shikoku Basin. J. Geomagn. Geoelectr., 32:567-573.

Gee, J., Staudigel, H., and Tauxe, L., 1989. Contribution of induced magnetization to magnetization of seamounts. Nature, 342:170-173.

Gee, J., Tauxe, L., Hildebrand, J.A., Staudigel, H., and Lonsdale, P., 1988. Non-uniform magnetization of Jasper Seamount. J. Geophys. Res., 93:12159-12175.

Hamano, Y., and Kinoshita, H., 1990. Magnetization of the oceanic crust inferred from magnetic logging in Hole 395A. In Detrick, R., Honnorez, J., Bryan, W.B., Juteau, T., et al., Proc. ODP, Sci. Results, 106/109: College

"Abbreviations for names of organizations and publications in ODP reference lists follow the style given in Chemical Abstracts Service Source Index (published by American Chemical Society). 
Station, TX (Ocean Drilling Program), 223-229.

Harland, W.B., Armstrong, R.L., Cox, A.V., Craig, L.E., Smith, A.G., and Smith, D.G., 1990. A Geologic Time Scale 1989: Cambridge (Cambridge Univ. Press).

IAGA Division V Working Group 8, 1991. International Geomagnetic Reference Field 1991 revision. J. Geomagn. Geoelectr., 43:1007-1012.

Kinoshita, H., Furuta, T., and Pariso, J., 1989. Downhole magnetic field measurements and paleomagnetism, Hole 504B, Costa Rica Ridge. In Becker, K., Sakai, H., et al., Proc. ODP, Sci. Results, 111: College Station, TX (Ocean Drilling Program), 147-156.

O'Reilly, W., 1984. Rock and Mineral Magnetism: New York (Chapman and Hall)

Pariso, J.E., and Johnson, H.P., 1993. Do layer 3 rocks make a significant contribution to marine magnetic anomalies? In situ magnetization of gabbros at Ocean Drilling Program Hole 735B. J. Geophys. Res., 98:16033-16052.

Pariso, J.E., Scott, J.H., Kikawa, E., and Johnson, H.P., 1991. A magnetic logging study of Hole 735B gabbros at the Southwest Indian Ridge. In Von Herzen, R.P., Robinson, P.T., et al., Proc. ODP, Sci. Results, 118: College Station, TX (Ocean Drilling Program), 309-321.

Ponomarev, V.N., and Nechoroshkov, V.L., 1983. First measurements of the magnetic field within the ocean crust: Deep Sea Drilling Project Legs 68 and 69. In Cann, J.R., Langseth, M.G., Honnorez, J., Von Herzen, R.P., White, S.M., et al., Init. Repts. DSDP, 69: Washington (U.S. Govt. Printing Office), 271-279.

Pozzi, J.-P., Barthés, V., Thibal, J., Pocachard, J., Lim, M., Thomas, T., and Pages, G., 1993. Downhole magnetostratigraphy in sediments: comparison with the paleomagnetism of a core. J. Geophys. Res., 98:7939-7957.
Pozzi, J.-P., Martin, J.P., Pocachard, J., Feinberg, H., and Galdeano, A., 1988. In situ magnetostratigraphy: interpretation of magnetic logging in sediments. Earth Planet. Sci. Lett., 88:357-373.

Sager, W.W., 1992. Seamount age estimates from paleomagnetism and their implications for the history of volcanism on the Pacific Plate. In Keating, B.H., and Bolton, B.R. (Eds.), Geology and Offshore Mineral Resources of the Central Pacific Basin. Circum.-Pac. Counc. Energy Miner. Resour., Earth Sci. Ser., 14:21-37.

Sager, W.W., Duncan, R.A., and Handschumacher, D.W., 1993. Paleomagnetism of the Japanese and Marcus-Wake seamounts, Western Pacific Ocean. In Pringle, M.S., Sager, W.W., Sliter, W.V., and Stein, S. (Eds.), The Mesozoic Pacific: Geology, Tectonics, and Volcanism. Geophys. Monogr., Am. Geophys. Union, 77:401-435.

Sager, W.W., and Han, H.C., 1993. Rapid formation of the Shatsky Rise oceanic plateau inferred from its magnetic anomaly. Nature, 364:610-613.

Sager, W.W., and Pringle, M.S., 1988. Mid-Cretaceous to Early Tertiary apparent polar wander path of the Pacific Plate. J. Geophys. Res., 93:11753-11771.

Sager, W.W., Winterer, E.L., Firth, J.V., et al., 1993. Proc. ODP, Init. Repts., 143: College Station, TX (Ocean Drilling Program).

Savitzky, A., and Golay, M.J.E., 1964. Smoothing and differential of data by simplified least square procedure. Anal. Chem., 36:1627-1639.

Date of initial receipt: 1 December 1993

Date of acceptance: 29 July 1994

Ms 143SR-239 